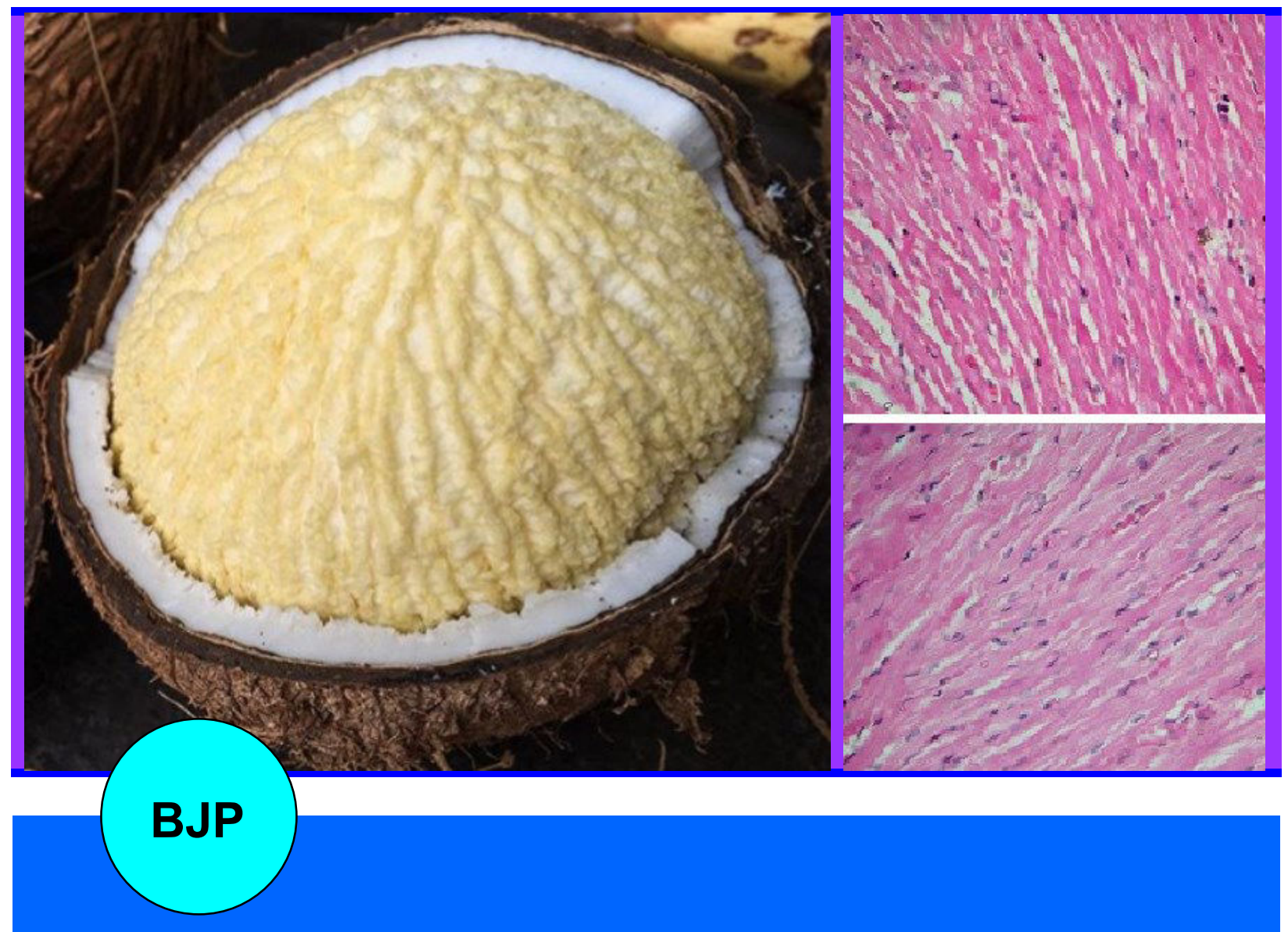

Bangladesh Journal of Pharmacology

Research Article

Dietary coconut sprout beneficially modulates cardiac damage induced by isoproterenol in rats 


\section{Dietary coconut sprout beneficially modulates cardiac damage induced by isoproterenol in rats}

\section{Anitha Madhusoodhanan Chikku and Thankappan Rajamohan}

Department of Biochemistry, University of Kerala, Kariavattom Campus, Thiruvananthapuram, Kerala, India.

\begin{tabular}{|c|c|}
\hline \multicolumn{2}{|l|}{ Article Info } \\
\hline Received: & 13 October 2012 \\
\hline Accepted: & 25 October 2012 \\
\hline Available Online: & 29 October 2012 \\
\hline \multicolumn{2}{|c|}{ DOI: 10.3329/bjp.v7i4.12143 } \\
\hline \multicolumn{2}{|c|}{$\begin{array}{l}\text { Cite this article: } \\
\text { Chikku AM and Rajamohan T. Die- } \\
\text { tary coconut sprout beneficially mod- } \\
\text { ulates cardiac damage induced by } \\
\text { isoproterenol in rats. Bangladesh J } \\
\text { Pharmacol. 2012; } 7 \text { : } 258-65 \text {. }\end{array}$} \\
\hline
\end{tabular}

\begin{abstract}
This work evaluates the cardioprotective potential of dietary coconut sprout (Cocos nucifera Linn.) on isoproterenol induced myocardial infarction in rats. Male Sprague Dawley rats were pretreated with coconut sprout $(50,100$ and $200 \mathrm{mg} / 100 \mathrm{~g}$ body weight) orally for 45 days and then cardiotoxicity was induced with isoproterenol ( $20 \mathrm{mg} / 100 \mathrm{~g}$ body weight) twice at an interval of 24 hours. Activity of cardiac marker enzymes were significantly increased in the serum and decreased in the heart of isoproterenol treated rats indicating cardiac damage. These effects were significantly reduced in coconut sprout pretreated rats. Moreover, pretreatment with coconut sprout increased antioxidant status and decreased oxidative stress in the heart. Histopathological examination revealed almost normal tissue morphology in the heart of these rats. These observed beneficial effects indicate that coconut sprout possesses significant cardioprotective and anti-oxidant properties.
\end{abstract}

\section{Introduction}

Cardiovascular diseases remain one of the leading causes of death worldwide despite of various advancements in treatment strategies. Among them myocardial infarction is occurring at an epidemic proportion throughout the world. Myocardial infarction is characterized by an irreversible necrosis of heart muscle secondary to prolonged ischemia. Heart failure subsequent to myocardial infarction is associated with antioxidant deficit as well as increased myocardial oxidetive stress (Michael and Pawan, 1996). Isoproterenol is a $\beta$-adrenergic agonist which is widely used to induce experimental myocardial infarction in rats. The pathophysiological changes following isoproterenol administration are comparable to those taking place in human myocardial ischemia/infarction (Wexler and Greenberg, 1978).

In recent times, attention has been focused on natural plant-derived materials in the prevention and management of cardiovascular diseases (Dipak et al., 2012;
Kerstin et al., 1999). A dietary supplement which can ameliorate myocardial infarction is of great importance because they augment the conventional treatment and offer better management of the condition with fewer side effects (Aman et al., 2011).

Coconut is consumed widely in many parts of the world. On germination of coconut the basal part of embryo, which is embedded in solid endosperm near the germinating pore, enlarges to form a cotyledonary structure called sprout (haustorium). Coconut sprout is one of the edible parts of coconut. Previous studies showed that coconut water and coconut kernel protein possess cardioprotective and antidiabetic properties (Anurag and Rajamohan, 2003; Mini and Rajamohan, 2002; Preetha et al., 2012; Salil and Rajamohan, 2011). But no scientific reports are available regarding the cardioprotective potential of coconut sprout in experimental myocardial infarction. Hence, we evaluated the cardioprotective effect of dietary supplementation of coconut sprout during isoproterenol-induced myocardial infarction in rats. 


\section{Materials and Methods}

\section{Coconut sprout}

Mature coconuts (12 months from flowering) of West Coast Tall variety were harvested from the Kerala University Campus and dried under shade for 22 days. Nuts of identical weights were placed in horizontal plain and two thirds of each nut was covered with soil. Soil moisture was maintained by periodical watering. Germinated nuts were randomly taken for the experiment 15 weeks after germination. It was dehusked, broken carefully and sprout was collected, ground and dried at $55^{\circ} \mathrm{C}$. Dried, finely powdered sprout was stored at $-4^{\circ} \mathrm{C}$ and used for experiments.

\section{Chemicals}

Isoproterenol hydrochloride was purchased from Sigma Chemical Co., USA. All other chemicals were purchased from Sisco Research Laboratories (SRL), Mumbai, India and were of analytical grade.

\section{Phytochemical analysis}

Phytochemical tests were carried out qualitatively to determine the various constituents in coconut sprout according to the methods outlined in Trease and Evans (Evans, 1996; 2002). Total carbohydrates, protein, fats, fiber, ash and free amino acids were estimated quantitatively (Sadasivam and Manickam, 1996). Ascorbic acid (Omaye et al., 1979), a-tocopherol (Baker et al., 1980) and total polyphenols (Malick and Singh, 1980) were also estimated.

\section{Experimental animals}

Male albino rats (Sprague-Dawley) weighing an average of 180-200 g were used for the experiment. All the animals were given standard rat chow (Sai feeds, India) and distilled water ad libitum. Temperature of the animal house was maintained at $25 \pm 5^{\circ} \mathrm{C}$ with alternate 12 hours period of light and dark. Food intake was recorded daily and body weight of rats were recorded weekly.

\section{Experimental design}

Rats were divided into six groups of eight each. Group I (normal control) and Group II (isoproterenol control) received normal saline and Group IV, V and VI received coconut sprout $(50,100$ and $200 \mathrm{mg} / 100 \mathrm{~g}$ body weight suspended in normal saline) orally for 45 days. Group III rats which received $200 \mathrm{mg}$ per $100 \mathrm{~g}$ body weight sprout for 45 days served as sprout control. After this period, isoproterenol $(20 \mathrm{mg} / 100 \mathrm{~g}$ body weight) was dissolved in normal saline and injected subcutaneously to rats of Group II, IV, V and VI at an interval of 24 hours for 2 days to induce myocardial infarction. 12 hours after the second dose of isoproterenol injection, rats were subjected to eutha- nasia by means of intraperitoneal injection of thiopentone sodium [ $>40 \mathrm{mg} / \mathrm{kg}$ body weight]. Blood samples and heart were collected for the estimation of various biochemical parameters.

\section{Biochemical estimations}

Creatinine kinase-MB (CK-MB) and lactate dehydrogenase (LDH) were estimated by the method of Rosalki (1967) and King (1965) respectively. Alanine transaminase (ALT) and aspartate transaminase (AST) activity were determined in serum and heart (Reitman and Frankel, 1957). Troponin T in serum was determined by highly specific enzyme immunoassay (EIA) (Katus et al., 1991). The activities of superoxide dismutase (SOD) and catalase in the heart were assayed as described by Kakkar (1984) and Maehly and Chance (1954). Reduced glutathione (GSH) was assayed by the method of Ellman (1959). Thiobarbituric Acid Reactive Substances (TBARS) and protein carbonyls in heart tissue were estimated according to the procedures of Ohkawa et al. (1979) and Levine et al. (1994) respectively.

\section{Histopathological analysis of heart}

The heart tissues were rapidly dissected out, washed in saline and fixed by immersion at room temperature in $10 \%$ formalin solution. For the histological examinations, paraffin embedded tissue sections of heart $(5 \mu \mathrm{m})$ were stained with hematoxylin-eosin. The sections were then examined under light microscope (Zeiss Axioscope 2 plus, USA) and photographed with Canon Zoom Browser EX, Japan.

\section{Statistical analysis}

Statistical analysis was performed by one-way analysis of variance (ANOVA) followed by Duncan's multiple range test (DMRT) using Statistical Package for Social Science (SPSS) version 17.0. Results were expressed as mean \pm SD for six rats in each group. " $p$ " values $<0.05$ were considered significant.

\section{Results}

Results show that sprout is rich in carbohydrates and proteins (Table I). It also contains bioactive components like vitamins, alkaloids and polyphenols.

In isoproterenol control rats (Group II), a significant increase in the activities of serum LDH, CK-MB, AST and ALT were observed as compared to normal control rats (Group I). A similar trend was observed in the level of cardiac troponin-T in serum. Rats pretreated with coconut sprout (Group IV, V, VI) showed significant decrease in the levels of these cardiac markers in serum during myocardial infarction compared to isoproterenol alone treated rats (Table II). Rats fed with $100 \mathrm{mg} / 100 \mathrm{~g}$ body weight sprout (Group V) showed minimum 


\section{Table I}

\section{Chemical constituents of coconut sprout}

\begin{tabular}{|lc|}
\hline Constituents & $\mathrm{g} / 100 \mathrm{~g}$ dried sprout \\
\hline Carbohydrates & $26.8 \pm 2.6$ \\
Protein & $18.0 \pm 1.7$ \\
Fat & $8.8 \pm 0.8$ \\
Fiber & $15.2 \pm 1.4$ \\
Ash & $7.8 \pm 0.8$ \\
Free amino acids & $0.9 \pm 0.1$ \\
Vitamin C & $0.1 \pm 0.0$ \\
Vitamin E & $0.1 \pm 0.0$ \\
Total polyphenols & $0.2 \pm 0.0$ \\
Values expressed as mean \pm SD of six experiments
\end{tabular}

marker enzymes in serum of sprout fed normal rats (Group III) was similar to that of normal control rats.

Figure 1 shows the activity of LDH, CK-MB, AST and ALT in the heart of experimental rats. Decrease in the activity of these enzymes was observed in isoproterenol induced rats compared to normal rats, where as significant increase in the activity was seen in rats pretreated with coconut sprout compared to isoproterenol induced rats. Enzyme activities in heart of group $\mathrm{V}$ rats were significantly similar to that of normal control rats.

SOD and catalase activity in the heart tissue of rats were shown in Table III. Decrease in the activity was seen in isoproterenol control rats compared to normal control rats and increase in activity was seen in sprout fed group IV, V and VI rats compared to isoproterenol control. Among the sprout treated rats group $\mathrm{V}$ rats

Table II

Effect of coconut sprout on serum myocardial infarction markers

\begin{tabular}{|c|c|c|c|c|c|}
\hline Groups & $\begin{array}{l}\text { Lactate dehydro- } \\
\text { genase (IU/L) }\end{array}$ & $\begin{array}{l}\text { CK-MB } \\
\text { (IU/L) }\end{array}$ & $\begin{array}{c}\text { AST } \\
\text { ( } \mu \mathrm{M} \text { of oxaloace- } \\
\text { tate liberated/ } \\
\text { min/mg protein) }\end{array}$ & $\begin{array}{c}\text { ALT } \\
\text { ( } \mu \text { M of pyruvate } \\
\text { liberated/min/ } \\
\text { mg protein) }\end{array}$ & $\begin{array}{c}\text { Troponin } \mathrm{T} \\
\text { (nM per } \mathrm{mL} \text { ) }\end{array}$ \\
\hline Normal & $520.0 \pm 49.9^{a}$ & $507.4 \pm 48.7 a$ & $149.1 \pm 14.3^{a}$ & $154.3 \pm 14.8^{\mathrm{a}}$ & $0.0 \pm 0.0^{a}$ \\
\hline Isoproterenol & $964.4 \pm 92.5^{b}$ & $855.8 \pm 82.1^{b}$ & $362.2 \pm 34.7 \mathrm{~b}$ & $191.4 \pm 18.4^{b}$ & $15.6 \pm 1.5^{b}$ \\
\hline $\begin{array}{l}\text { Coconut sprout (200 } \\
\mathrm{mg})\end{array}$ & $516.8 \pm 49.6^{a}$ & $512.0 \pm 50.6^{a}$ & $150.8 \pm 14.5^{\mathrm{a}}$ & $152.4 \pm 14.6^{a}$ & $0.0 \pm 0.0^{a}$ \\
\hline $\begin{array}{l}\text { Coconut sprout ( } 50 \\
\mathrm{mg})+ \text { isoproterenol }\end{array}$ & $766.9 \pm 73.6^{c}$ & $738.5 \pm 78.9 c$ & $261.8 \pm 25.1^{c}$ & $166.7 \pm 16.0^{\mathrm{a}}$ & $2.4 \pm 0.2 c$ \\
\hline $\begin{array}{l}\text { Coconut sprout }(100 \\
\mathrm{mg})+ \text { isoproterenol }\end{array}$ & $572.7 \pm 54.9 \mathrm{a}, \mathrm{d}$ & $533.2 \pm 51.2^{\mathrm{a}, \mathrm{d}}$ & $165.1 \pm 15.8^{a}$ & $157.4 \pm 15.1^{\mathrm{a}}$ & $0.7 \pm 0.1^{\mathrm{a}, \mathrm{d}}$ \\
\hline $\begin{array}{l}\text { Coconut sprout (200 } \\
\mathrm{mg})+ \text { isoproterenol }\end{array}$ & $628.7 \pm 60.3^{d}$ & $592.5 \pm 56.8^{d}$ & $155.3 \pm 14.9^{a}$ & $165.0 \pm 16.7^{a}$ & $1.0 \pm 0.1^{\mathrm{d}}$ \\
\hline
\end{tabular}

\section{Table III}

Effect of coconut sprout on superoxide dismutase, catalase and reduced glutathione in the heart tissue

\begin{tabular}{|c|c|c|c|}
\hline Groups & $\begin{array}{l}\text { Superoxide dismutase } \\
\text { (Units/mg protein) }\end{array}$ & $\begin{array}{c}\text { Catalase } \\
\left(\times 10^{-3} \text { units } / \mathrm{mg} \text { protein }\right)\end{array}$ & $\begin{array}{l}\text { Reduced glutathione } \\
\text { (mM/100 g wet tissue) }\end{array}$ \\
\hline Normal & $11.2 \pm 1.1^{\mathrm{a}, \mathrm{c}}$ & $10.4 \pm 1.0^{\mathrm{a}}$ & $426.0 \pm 40.9^{a}$ \\
\hline Isoproterenol & $4.3 \pm 0.4^{\mathrm{b}}$ & $3.9 \pm 0.4^{\mathrm{b}}$ & $228.9 \pm 22.0^{b}$ \\
\hline Coconut sprout (200 mg) & $11.5 \pm 1.1^{c}$ & $10.8 \pm 1.0^{a}$ & $430.2 \pm 41.3^{\mathrm{a}}$ \\
\hline Coconut sprout $(50 \mathrm{mg})+$ isoproterenol & $7.4 \pm 0.7 \mathrm{~d}$ & $6.2 \pm 0.6^{c}$ & $283.1 \pm 27.2^{c}$ \\
\hline Coconut sprout $(100 \mathrm{mg})+$ isoproterenol & $10.4 \pm 1.0^{\mathrm{a}, \mathrm{e}}$ & $9.2 \pm 0.9^{\mathrm{d}}$ & $385.0 \pm 36.9^{d}$ \\
\hline Coconut sprout $(200 \mathrm{mg})+$ isoproterenol & $9.6 \pm 0.9 \mathrm{e}$ & $8.4 \pm 0.8^{d}$ & $297.6 \pm 29.6^{c}$ \\
\hline
\end{tabular}

increase in the activities of these cardiac marker enzymes in serum indicating better cardioprotection among the doses of coconut sprout studied. Activity of showed activity near to normal control rats. Similar result was seen in the case of reduced glutathione. 


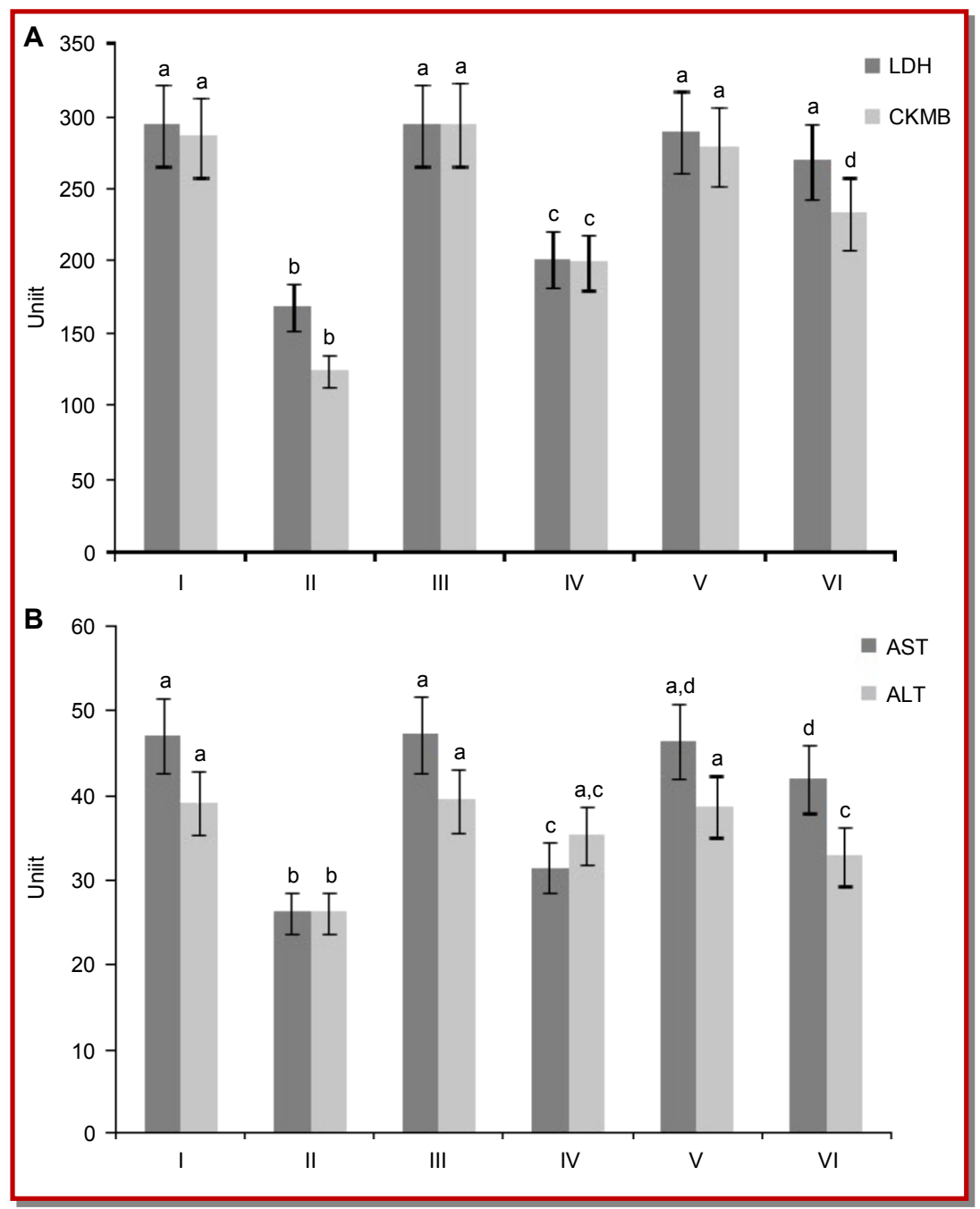

Figure 1: Activity of marker enzymes in heart. A) LDH and CK-MB; B) AST and ALT in heart tissue.

Group I Normal, group II Isoproterenol, group III Coconut sprout $(200 \mathrm{mg})$, group IV Coconut sprout $(50 \mathrm{mg})+$ isoproterenol, group V Coconut sprout $(100 \mathrm{mg})+$ isoproterenol, group VI Coconut sprout $(200 \mathrm{mg})+$ isoproterenol. LDH expressed in $\mu \mathrm{M}$ of NAD+ liberated/min/mg protein, CK$\mathrm{MB}$ in $\mu \mathrm{M}$ of phosphorus liberated/min/mg protein, AST in $\mu \mathrm{M}$ of oxaloacetate liberated/min/mg protein and ALT in $\mu \mathrm{M}$ of pyruvate liberated/ $\mathrm{min} / \mathrm{mg}$ protein. Values expressed as mean $\pm \mathrm{SD}$ for six rats in each group. Values not sharing a common superscript $(\mathrm{a}, \mathrm{b}, \mathrm{c}, \mathrm{d})$ differ significantly at $\mathrm{p}<0.05$ (DMRT)

Group II rats showed significantly higher amount of peroxidation markers compared to normal rats (Figure 2). This increase in TBARS and protein carbonyls were significantly reversed in group IV, V and VI compared to group II rats. Peroxidation was lower in group V rats among isoproterenol induced groups.

Histopathology of heart (Figure 3) of isoproterenol administered rats showed marked edema, vascular constriction, inflammatory infiltration of leucocytes, necrosis and loss of striations with nuclear changes while the heart of control rat showed normal myocardial fibers. Sprout control rats showed no perceptible changes in the heart when compared to normal control rats. Heart of sprout pretreated rats given isoproterenol showed only mild focal inflammation compared to the heart of isoproterenol alone administered rats. Moreover, myocyte proliferation was observed in coconut sprout pretreated groups.

\section{Discussion}

In this study, myocardial infarction was induced in rats using isoproterenol as described by us earlier (Anurag and Rajamohan, 2003). Myocardial damage was estimated by measuring the activity of cardiac marker enzymes. The tissue specificity of enzymes make them the markers of tissue damage (Hearse, 1979). Damage to myocardial cells, containing CK-MB, LDH, AST and ALT due to deficient oxygen supply during myocardial infarction, results in the leakage of these enzymes (Mitra and Panj, 2005). This accounts for the increased activity of these enzymes in serum and decreased activity in heart tissue of rats induced with myocardial infarction. Our results showed that, in isoproterenol- 


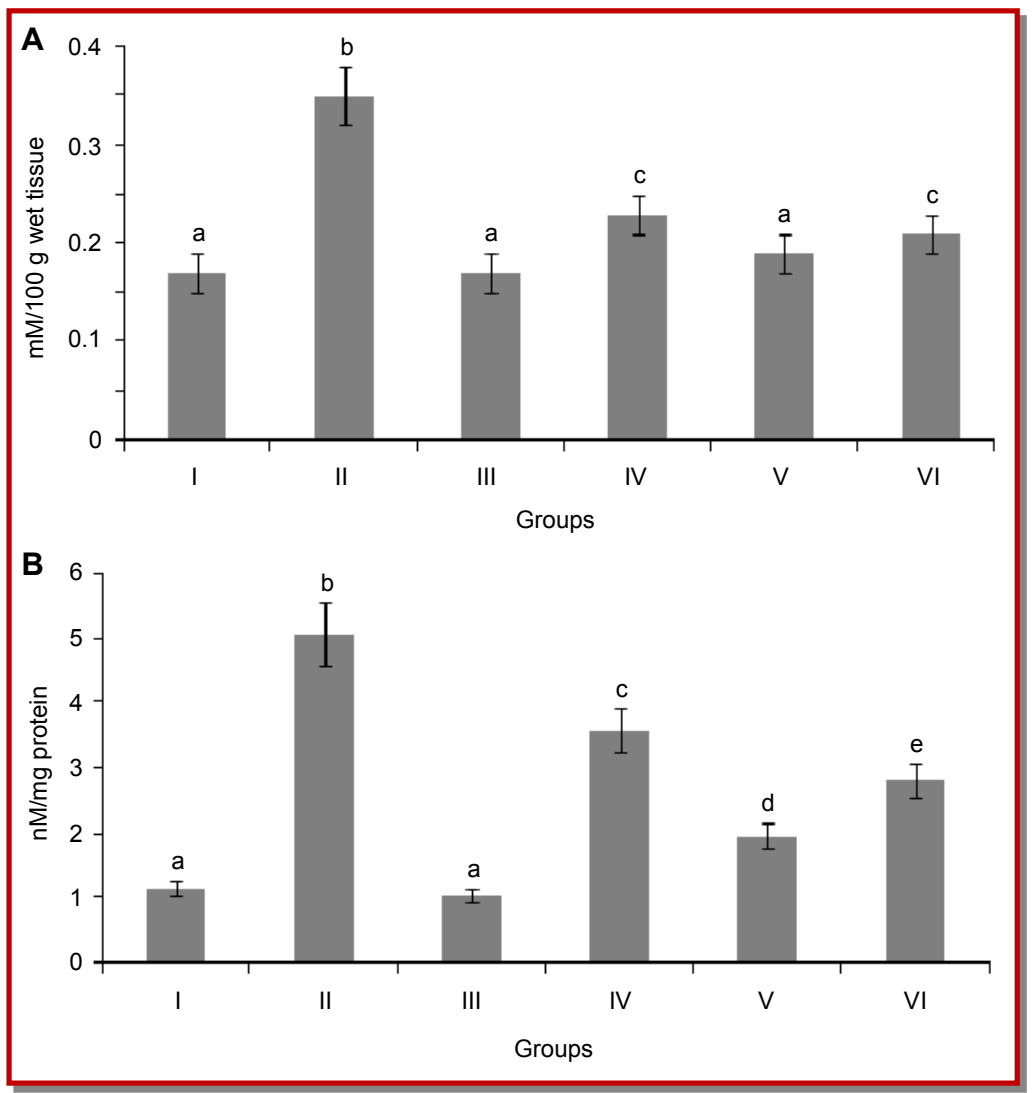

Figure 2: Level of peroxidation products in heart tissue. (A) TBARS; (B) Protein carbonyl value. Values are mean \pm SD for six rats in each group. Values not sharing a common superscript differ significantly at $\mathrm{p}<0.05$ (DMRT)

induced group II, IV, V and VI the activity of these cardiac marker enzymes increased in serum and decreased in heart. But coconut sprout pretreated rats (Group IV, V and VI) showed lower activities of CKMB, LDH, AST and ALT in the serum and higher activity in heart. Cardiac specific troponin T, which is a regulatory protein of myocyte contraction, was another important diagnostic marker, released into circulation in response to myocardial necrosis. Serum level of cardiac Troponin $\mathrm{T}$ was high in isoproterenol control rats where as it was lower in coconut sprout pretreated groups. This might be due to the protective effect of sprout on heart, which had reduced the extent of cardiac damage induced by isoproterenol and thereby restricting the leakage of these enzymes and troponin $\mathrm{T}$ from myocardium.

Isoproterenol induction caused reduction in cardiac SOD and catalase activities which is consistent with similar findings in a number of earlier studies (Manjula et al., 1993; Sangeetha and Darlin, 2006). In myocardial infarction, the increased production of superoxide radicals and hydrogen peroxide inactivates SOD and catalase resulting in the loss of activity and accumulation of superoxide anion and hydrogen peroxide, thus damaging the myocardial cells (Karthikeyan et al., 2005; Menu et al., 2001; Rajadurai et al., 2005). A decrease in the concentration of GSH was seen in isoproterenol induced rats. Glutathione participates directly in the destruction of hydrogen peroxides and also promotes the formation of reduced form of ascorbate which has high anti-oxidant activity (Martensson and Meister, 1991). GSH-dependent enzymes provide a second line of defence as they primarily detoxify the noxious byproducts generated by ROS and also help to prevent propagation of free radicals (Gumieniczek, 2005). Decreased GSH levels observed in myocardial infarcted rats might be due to its increased utilization in protecting $\mathrm{SH}$ groups containing proteins from the action of free radicals (Sheela Sasikumar and Shyamaladevi, 2000).

Pre-treatment with coconut sprout increased the activities of catalase, SOD and concentration of GSH in isoproterenol treated rats. An increase in lipid peroxidation and protein oxidation indicated by elevated levels of TBARS and protein carbonyls were observed in isoproterenol administered rats. Elevation of lipid peroxides subsequent to myocardial infarction results in the initiation of the chain reactions that could damage the myocardium. The observed increase in the lipid and protein peroxidation enhances myocardial injury and impairs the anti-oxidant defence mechanism to prevent the formation of excess free radicals. Pre- 

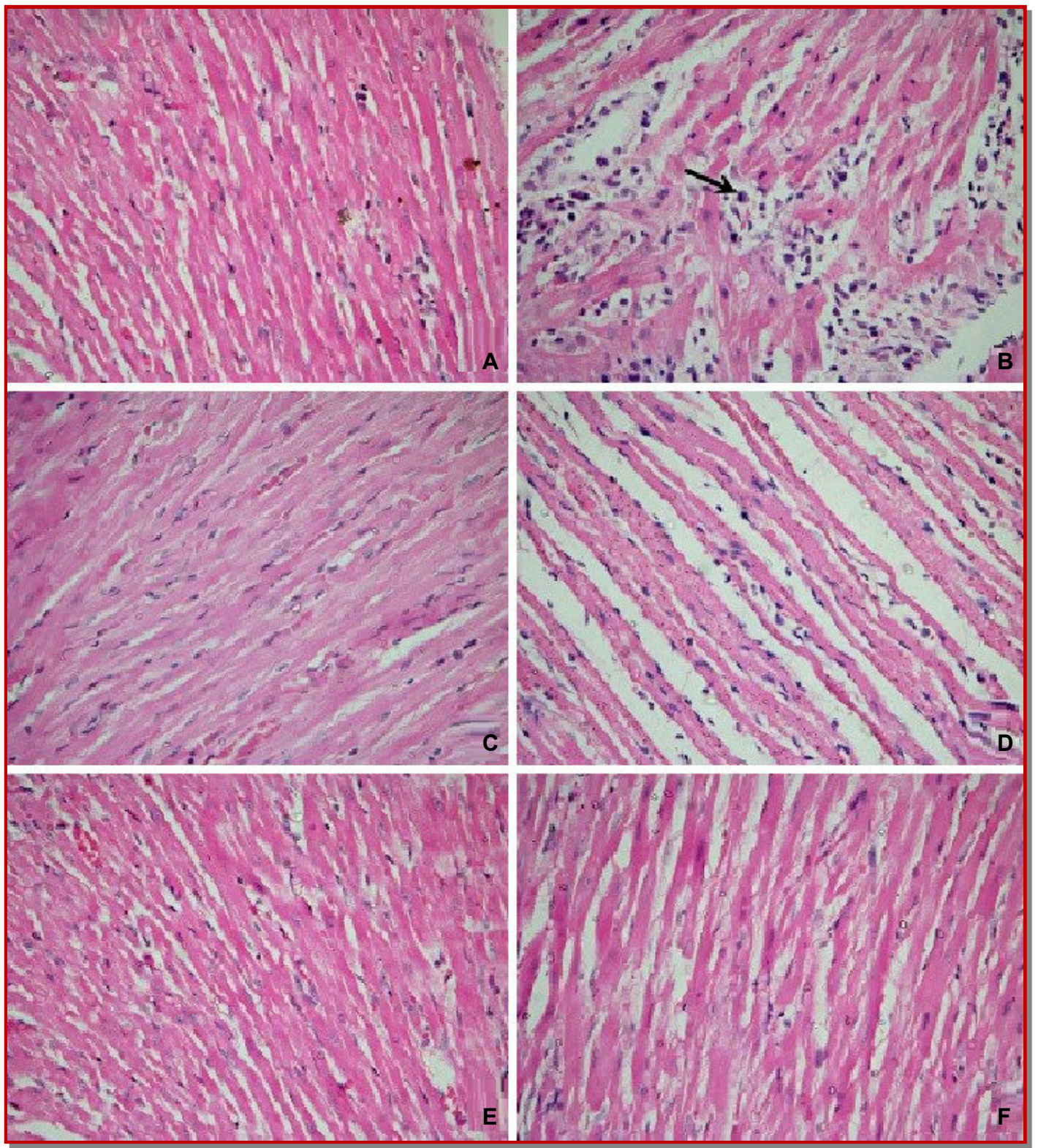

Figure 3: Photomicrographs of Haematoxylin and Eosin staining of heart X400.

A) Control rat heart showing normal architecture of myocytes; B) isoproterenol-control group heart showing necrosis of muscle fiber with inflammatory cell infiltration, edema along with extravasation of red blood cells; C) coconut sprout ( $200 \mathrm{mg} / 100 \mathrm{~g})$ alone treated rat heart showing normal cardiac fibers; D) coconut sprout $50 \mathrm{mg} / 100 \mathrm{~g}+$ isoproterenol showing edema with inflammatory cell infiltration; E) coconut sprout $100 \mathrm{mg} / 100 \mathrm{~g}+$ isoproterenol showing almost normal myocardial cells; F) coconut sprout $200 \mathrm{mg} / 100 \mathrm{~g}+$ isoproterenol treated heart tissue showing mild inflammatory infiltration and mild edema but no infarction

treatment with coconut sprout lowered the concentration of TBARS and protein carbonyls in isoproterenol treated rats. This shows the cardioprotective role of coconut sprout associated with its anti-oxidant effects.

Histopathological examination of heart of isoproterenol administered rat showed focal lesions and fragmentation of muscle fibers, hyaline necrosis and edema. In rats pretreated with coconut sprout, normal structure with very little evidence of inflammatory infiltration was observed. This reduced density of inflammatory cells indicated that coconut sprout protected the myocardium from isoproterenol-induced damage which also confirms its cardioprotective activity.

Among the various doses of coconut sprout administered, $100 \mathrm{mg} / 100 \mathrm{~g}$ body weight is more effective in reducing the cardiac damage induced by isoproterenol. The chemical analysis of coconut sprout revealed that it contains proteins, vitamins, minerals, alkaloids and polyphenols. Polyphenols, alkaloids and vitamins are reported to scavenge free radicals and decreases 
oxidative stress and thereby reduce the isoproterenol induced pathogenesis of myocardial infarction (Cheng et al., 2012; Li et al., 2010; Mukesh et al., 2007). The beneficial effects of coconut sprout in reducing oxidative stress and protecting cardiac tissue may be due to the presence of these biologically active components. The present study provides first evidence on the effect of coconut sprout against isoproterenolinduced myocardial infarction in rats.

\section{Conclusion}

Dietary supplementation of coconut sprout is helpful in protecting heart during myocardial infarction.

\section{Ethical Issue}

The animal experiments were approved by the Institutional Animal Ethics Committee of the University of Kerala. The laboratory guidelines of the Committee for the Purpose of Control and Supervision of Experiments on Animals (CPCSEA), India for the use and care of animals were followed throughout the experimental period.

\section{Acknowledgement}

Financial assistance from Council of Scientific and Industrial Research (CSIR), India, in the form of Junior Research Fellowship to A.M. Chikku is gratefully acknowledged.

\section{References}

Aman U, Hardik G, Balaraman R. Isoproterenol Induced Myocardial infarction: Protective role of natural products. J Pharmacol Toxicol. 2011; 6: 1-17.

Anurag P, Rajamohan T. Cardioprotective effect of tender coconut water in experimental myocardial infarction. Plant Foods Hum Nutr. 2003; 58: 1-12.

Baker H, Frankel O, De Angells B, Feingold S. Plasma atocopherol in man at various times after ingesting free or acetylated tocopherol. Nutr Rep Int. 1980; 21: 531-36.

Cheng D, Zhu C, Cao J, Jiang W. The protective effects of polyphenols from jujube peel (Ziziphus Jujube Mill) on isoproterenol-induced myocardial ischemia and aluminuminduced oxidative damage in rats. Food Chem Toxicol. 2012; 50: $1302-08$.

Dipak KP, Swati ND, Hardik PG, Ranjitsinh VD, Ramachandran AV. Cardi protective effect of Coriandrum sativum L. on isoproterenol induced myocardial necrosis in rats. Food Chem Toxicol. 2012; 50: 3120-25.

Ellman GL. Tissue sulfhydryl groups. Arch Biochem Biophys. 1959; 82: 70-77.

Evans WC. In: Trease and Evans Pharmacognosy. 13 $3^{\text {th }}$ ed. USA, W.B. Saunder Company limited, 1996, pp 100-20.
Evans WC. In: Trease and Evans Pharmacognosy. $15^{\text {th }}$ ed. New York, Elsevier Science Limited, 2002, pp 156-200.

Gumieniczek A. Effects of rapaglinide on oxidative stress in tissues of diabetic rabbits. Diabetes Res Clin Pr. 2005; 68 :89_ 95.

Hearse DJ. Enzymes in cardiology. In: Cellular damage during myocardial ischaemia: Metabolic changes leading to enzyme leakage. Hearse DJ, De Leiris J, Losiance D (eds). New York, Wiley, 1979, pp 1-21.

Kakkar P, Das B, Viswanathan PN. A modified spectrophotometric assay of superoxide dismutase. Indian J Biochem Biophys. 1984; 2: 130-32.

Karthikeyan K, Sarala Bai BR, Gauthaman K, Niranjali Devaraj S. Protective effect of propyl gallate against myocardial oxidative stress-induced injury in rats. J Pharm Pharmacol. 2005; 57: 67-73.

Katus HA, Remppis A, Neumann FJ, Scheffold T, Diederich KW, Vinar G. Diagnostic efficacy of troponin $T$ measurements in acute myocardial infarction. Circulation 1991; 83: 902-12.

Kerstin KG, Johanna MG, Johanna HB, Heiner B, Albert $\mathrm{H}$, Diederick EG, Jacqueline CMW. Dietary anti-oxidants and risk of myocardial infarction in the elderly: The Rotterdam Study. Am J Clin Nutr. 1999; 69: 261-66.

King J. The dehydrogenases or oxidoreductases- Lactate dehydrogenase. In: Practical Clinical Enzymol. Van D (eds). London, Nostrand, 1965, pp 83-93.

Levine RL, Williams JA, Stadman ER, Shacter E. Carbonyl assays for determination of oxidatively modified proteins. Methods in Enzymol. 1994; 233: 346-57.

Li X, Zhou R, Zheng P, Yan L, Wu Y, Xiao X, Dai G. Cardioprotective effect of matrine on isoproterenol-induced cardiotoxicity in rats. J Pharm Pharmacol. 2010; 62: 514-20.

Maehly AC, Chance B. Assay of catalases and peroxidases. Method Biochem Anal. 1954; 1: 357-424.

Mallick CP, Singh MB. Plant enzymology and Histoenzymology. New Delhi, Kalyani publishers, 1980, p 286.

Manjula TS, Deepa R, Shyamala Devi CS. Effect of aspirin on lipid peroxidation in experimental myocardial infarction in rats. J Nutr Biochem. 1993; 5: 95-98.

Martensson J, Meister A. Glutathione deficiency decreases tissue ascorbate levels in new born rats: Ascorbate spares glutathione and protects. Proc Nat Aca Sci. 1999; 88: 465660 .

Menu S, Kamal K, Gupta SK, Joshi S, Arya DS. Cardioprotective potential of Ocimum sanctum in isoproterenol induced myocardial infarction in rats. Mol Cell Biochem. 2001; 225: 75-83.

Michael FH, Pawan KS. Anti-oxidant and oxidative stress changes during heart failure subsequent to myocardial infarction in rats. Am J Pathol. 1996; 148: 291-300.

Mini S, Rajamohan T. Cardioprotective effect of coconut kernel protein in isoproterenol administered rats. Indian J Biochem 
Biophys. 2002; 39: 197-200.

Mitra B, Panja M. Myocardial metabolism: Pharmacological manipulation in myocardial ischaemia. J Assoc Physicians India. 2005; 53: 552-60.

Mukesh N, Ipseeta M, Nag TC, Shreesh KO, Rajan, M, Santosh $\mathrm{K}$, Dharamvir SA. Cardioprotective response to chronic administration of vitamin $\mathrm{E}$ in isoproterenol induced myocardial necrosis: Hemodynamic, biochemical and ultrastructural studies. Ind J Clin Biochem. 2007; 22: 22-28.

Ohkawa H, Ohnishi N, Yag K. Assay of lipid peroxidation in animal tissue by thiobarbituric acid reaction. Anal Biochem. 1979; 95: 351-58.

Omaye DW, Emery G, Maynard JE. Selected methods for the determination of ascorbic acid in animal cells, tissues, and fluids. Methods in Enzymol. 1979; 62: 3-11

Preetha PP, Devi VG, Rajamohan T. Hypoglycemic and antioxidant potential of coconut water in experimental diabetes. Food Funct. 2012; 3: 753-57.

Rajadurai M, Padmanaban M, Stanely Mainzen Prince P. Effect of Agelem armelos leaf extract and a-tocopherol on lipid peroxidation and anti-oxidants in isoproterenol induced myocardial infarction in rats. Cardiology 2005; 1: 40-45.
Reitman S, Frankel S. A colourimetric method for the determination of serum glutamic oxaloacetic acid and glutamine pyruvate transaminase. Am J Clin Pathol. 1957; 28: 56-63.

Rosalki SB. An improved procedure for serum creatinine phosphokinase. J Lab Clin Med. 1967; 69: 696-705.

Sadasivam S, Manickam A. Biochemical methods. $2^{\text {nd }}$ ed. New Delhi, New Age International Publishers, 1996, pp 8-194

Salil G, Nevin KG, Rajamohan T. Arginine rich coconut kernel protein modulates diabetes in alloxan treated rats. ChemBiol Interact. 2011; 189: 107-11.

Sangeetha T, Darlin Quine S. Anti lipoperoxidative and antioxidant effects of S-allyl cysteine sulfoxide on isoproterenolinduced myocardial infarction in Wistar Rats. J Biochem Mol Toxic. 2006; 20: 167-73.

Sheela Sasikumar C, Shyamaladevi CS. Protective effect of Abana: A polyherbal formulation, on isoproterenol induced myocardial infarction in rats. Indian J Pharmacol. 2000; 32: 198-201.

Wexler BC, Greenberg BP. Protective effects of clofibrate on isoproterenol-induced myocardial infarction in arteriosclerotic and non-arteriosclerotic rats. Atherosclerosis 1978; 29: 373-95. 